\title{
Habitat type, food resources, noise and light pollution explain the species composition, abundance and stability of a winter bird assemblage in an urban environment
}

\author{
Michał Ciach $^{1}$ • Arkadiusz Fröhlich ${ }^{1}$ \\ Published online: 21 November 2016 \\ (C) The Author(s) 2016. This article is published with open access at Springerlink.com
}

\begin{abstract}
At present, urban areas cover almost 3\% of the Earth's terrestrial area, and this proportion is constantly increasing. Although urbanization leads to a decline in biodiversity, at the same time it creates extensive habitats that are exploited by an assemblage of organisms, including birds. The species composition and density of birds nesting in towns and cities are determined by the types of buildings, the structure and maturity of urban greenery, and habitat diversity. In contrast, the habitat traits shaping the community of birds wintering in urban areas are not known. The aim of this work was to assess the influence of habitat structure, food resources and the urban effects (pollution, noise, artificial light) on an assemblage of birds overwintering in an urban area. It was carried out in 2014 and 2015 in the city of Kraków (southern Poland), on 56 randomly chosen sample plots, in which the composition, density and interseasonal similarity of bird assemblage were assessed with line transect method. A total of 64 bird species (mean $=17.7 \pm 4.9 \mathrm{SD}$ species/plot) was recorded. The mean density was 89.6 ind./km $\pm 63.3 \mathrm{SD}$. The most numerous species were Great Tit Parus major, Magpie Pica pica, Blackbird Turdus merula, Blue Tit Cyanistes caeruleus, Rook Corvus frugilegus, Fieldfare Turdus pilaris and House Sparrow Passer domesticus. Noise adversely affected species numbers and density, but artificial light acted positively on the density of birds and their interseasonal stability. The species richness and density of birds were also determined by the number of food sources available (e.g.
\end{abstract}

Michał Ciach

michal.ciach@ur.krakow.pl

1 Department of Forest Biodiversity, Institute of Forest Ecology and Silviculture, Faculty of Forestry, University of Agriculture, al. 29 Listopada 46, 31 - 425 Kraków, Poland bird-feeders). In addition, the greater the proportion of open areas, the fewer species were recorded. In contrast, the more urban greenery there was, the greater the density of the entire bird assemblage. Urban infrastructure (buildings, roads, refuse tips) had a positive effect on the interseasonal stabilization of the species composition of wintering birds. The results of this work indicate that the urban effect, i.e. noise and light pollution, apart from purely habitat factors, provide a good explanation for the species richness, density and stability of bird assemblage wintering in urban areas.

Keywords Urbanization · Urban ecology · Urban effect . Species diversity $\cdot$ Fauna homogenization

\section{Introduction}

At present urban areas account for almost 3\% of the Earth's land surface, and this proportion is continually rising (Liu et al. 2014). Consequently, urbanization is regarded as one of the main threats to wildlife, the most significant cause of the extinction of species (Czech et al. 2000; Sushinsky et al. 2013). The deleterious effects of urbanization are potentiated by its ever stronger influence on pristine, naturally extremely valuable areas (Marzluff 2001; Mcdonald et al. 2008). At the same time, the presence of wildlife in urban areas improves people's quality of life (van Kamp et al. 2003). Since towns and cities are inhabited by more than half the human population (UNFPA 2014), the preservation of the greatest possible biodiversity is of crucial significance to their inhabitants and is taken into account in town planning policies (Mcintyre et al. 2000; Sushinsky et al. 2013).

On the one hand urbanization leads to an overall decline in biodiversity, but on the other to a concentration and increase in the abundance of populations of synanthropic bird species 
(Czech et al. 2000; McKinney 2002). Factors favouring species inhabiting towns and cities include the permanent supply of food (Rodewald and Shustack 2008; Tryjanowski et al. 2015b), mild temperatures (Jadczyk and DrzenieckaOsiadacz 2013), the availability of suitable nesting and roosting sites (Sacchi et al. 2002), the lower level of natural predation pressure (Gering and Blair 1999) and artificial light, which prolongs diurnal activity (Longcore and Rich 2004; Miller 2006). In sum, urban areas offer suitable living conditions to synanthropic bird species, the consequences of which are an extended breeding season, a high level of reproductive success and higher densities than in natural ecosystems (Møller 2009; Jadczyk and Drzeniecka-Osiadacz 2013). All this encourages certain species to move into urban areas, so that their numbers are increasing there faster than in rural areas (Møller et al. 2014).

Urban environments offer appropriate conditions for flexible species, and they do indeed achieve high numbers there (Jokimaki et al. 1996). In contrast, such areas have a deleterious effect on sensitive (stenotopic) species, which avoid them because they do not offer suitable habitats, or these are degraded or fragmented. Increased mortality, poor individual condition and low productivity of urban populations are due to high levels of air, water and soil pollution (McDonnell 1997; Marzluff 2001), and also to vibrations and noise, which force birds to expend more energy on communication (Francis et al. 2009; Nemeth et al. 2013). Further deleterious factors include road traffic (Forman et al. 2002; Bujoczek et al. 2011) and tall buildings (Longcore and Rich 2004), both of which give rise to collisions, which in turn reduce numbers of birds.

The richness of the breeding bird community in towns and cities is shaped by a set of habitat factors that includes the types of buildings, the maturity of urban greenery, the number and size of trees, as well as the diversity, patch size, fragmentation and spatial configuration of habitats (Crooks 2004; Palomino and Carrascal 2006; Stagoll et al. 2012). Apart from these habitat factors, the urban bird community is affected by another set of factors that are consequent upon its existence and functioning, which we can call the urban effect. This consists of pollutant emissions (Ciach and Fröhlich 2013), artificial light (Miller 2006), noise (Nemeth et al. 2013), as well as the economic conditions (Czech et al. 2000) and density of the human inhabitants (Lepczyk et al. 2004).

For large proportions of the populations of many shortdistance migrants towns and cities are crucial as wintering areas (Pulliainen 1963; Meissner et al. 2012; Møller et al. 2014); they are also an important habitat for numerous sedentary species (Sacchi et al. 2002; Møller et al. 2014). In addition, some species that do not breed in urban areas nonetheless concentrate there in winter (Jokimaki et al. 1996; Bellebaum 2005; Meissner et al. 2012; Jadczyk and Drzeniecka-Osiadacz 2013), which increases their density significantly in comparison with non-urbanized areas (Lancaster and Rees 1979; Jokimaki et al. 1996; Tryjanowski et al. 2015c).

To date, most studies of the factors governing the urban bird community have been carried out during the breeding season; in consequence, the ecology of birds wintering in urban areas is poorly known (Jokimäki and Kaisanlahti-Jokimäki 2012; Jadczyk and Drzeniecka-Osiadacz 2013). The relatively well-known factors affecting the bird community of natural and semi-natural areas may not be applicable; indeed, their influence may be entirely different (Lancaster and Rees 1979; Jokimaki et al. 1996). Even though the areas of urbanized land are increasing very rapidly, the role they play as wintering grounds for birds is still poorly understood, and how urban habitat structure and the urban effect interplay with the bird community in such environments is not known at all.

The aims of this study are: 1) to characterize the assemblage of birds overwintering in urban areas, and 2) to assess the influence of habitat structure, food resources and the urban effect on the species composition, density and stability of wintering birds. To date, wintering bird assemblages have been examined in the context of purely habitat factors; the urban effect on them has not been studied. To the best of our knowledge, this is the first attempt to undertake a joint analysis of the parts played by both habitats and the urban effect in shaping the winter bird communities of towns and cities.

\section{Methodology}

\section{Study area}

This study was carried out in the city of Kraków (southern Poland, $50^{\circ} 05^{\prime} \mathrm{N}, 19^{\circ} 55^{\prime} \mathrm{E}$ ). It covers an area of $327 \mathrm{~km}^{2}$ and has a population density of 2321 persons $/ \mathrm{km}^{2}$ (GUS 2014). Kraków is characterized by a broad urbanization gradient from the densely built-up city centre, through the suburbs with a moderate number of buildings to the scattered buildings typical of a rural landscape. The city's buildings cover around $6 \%$ of its overall area. The types of buildings range from the compact, continuous structures that cover the ground completely through taller and shorter blocks of flats to detached and semi-detached houses, with varying amounts of greenery in between (MIIP 2015). The urban greenery is made up of native and non-indigenous species in various spatial arrangements, forms of management and stages of succession. One hundred different types of natural plant community have been identified in Kraków (Dubiel and Szwagrzyk 2008). Urban greenery is the predominant form of vegetation in the city (47\%), consisting of gardens (14\%), squares, road verges and playgrounds (10\%), allotments and orchards (4\%), parks and cemeteries $(3 \%)$ and other green areas $(15 \%)$. The next most common group of habitats consists of open areas (37\%): arable land (14\%), spontaneous ruderal communities (13\%), 
meadows and pastures $(8 \%)$, wetland vegetation $(2 \%)$. The remainder of the city's green areas consists of forests and natural woodland (11\%): natural and semi-natural scrub $(5 \%)$, deciduous and mixed forest (4\%) and damp, riparian forest and transformed tree stands (2\%). Roads and railway lines make up $4 \%$ and surface waters just $1 \%$ of the city's area (Dubiel and Szwagrzyk 2008). The principal waterway in Kraków is the River Wisła (Vistula); six medium-sized tributaries and numerous smaller watercourses flow into the Wisła within the city limits (MIIP 2015). The quality of air in Kraków is among the worst in Europe, containing high levels of suspended particulate matter, nitrogen dioxide and benzo(alpha)pyrene (WIOŚ 2014; AQIE 2015).

\section{Selection of sample plots; bird counts}

Fifty-six sample plots on which birds were to be counted (Fig. 1) were selected at random using Quantum GIS software (QGIS 2013). In the first step, Kraków was divided into 389 $1 \mathrm{~km} \times 1 \mathrm{~km}$ squares from which the sample plots were drawn. The grid of squares was based on a point with coordinates $50^{\circ} \mathrm{N} 20^{\circ} \mathrm{E}$. Then, every square was subdivided into four smaller squares of sides $500 \mathrm{~m} \times 500 \mathrm{~m}$; one of these was chosen at random for the counts. On every study plot two transects each $500 \mathrm{~m}$ long were marked out. They ran longitudinally or latitudinally (the ideal transect). Obstacles in the terrain (existing buildings, fences, walls etc.) caused the real transects to deviate from the ideal and ran along existing roads or paths.

Birds were censused during winter in 2014 and 2015. Two surveys were carried out each year: early winter (03.01-30.01) and late winter (01.02-28.02). A period of at least two weeks had to elapse between consecutive surveys. Counting was done using the linear transect method (Bibby et al. 2000). All birds seen or heard up to $100 \mathrm{~m}$ on either side of the transect were counted. Birds recorded further than $100 \mathrm{~m}$ from the transect or flying over it were not included in the analysis. Birds were counted between 08:00 and 15:00 h CET, only on rain-free, snow-free and windless days. The transects were walked at an average speed of $2 \mathrm{~km} / \mathrm{h}$.

\section{Environmental variables}

The habitat parameters were defined within the boundaries of the sample plots based on existing spatial database resources using GIS tools and also on the fieldwork (Table 1). The surface areas of urban greenery (GREENERY), forest and natural woodland (FORESTS) and open spaces (OPENAREAS) were calculated using the polygon vector layer of the atlas of the real vegetation of Kraków (UMK 2012), which is the effect of fieldwork done in 2006 (Dubiel and Szwagrzyk 2008). The atlas categorises the city area into 58 habitat types, which have been allocated to one of the three habitat groups stated above. A separate polygon vector layer was created for each habitat group. Urban greenery (GREENERY) included cultivated green areas (parks, cemeteries, squares etc.), the spontaneous greenery of developed land, and garden greenery (house gardens, allotments and orchards). Forests and natural woodlands (FORESTS) included deciduous forest, mixed woodland and naturally growing shrubs. Open spaces (OPENAREAS) included arable land, meadows, pastures, uncultivated and fallow land, rock vegetation, swards, heaths and the communities of trampled areas. Each of these layers was reduced by the layer containing the outlines of buildings (WODGiK 2009) and the layer of surface waters (MIIP 2015), which yielded the actual surface area of a given habitat.

The area of roads and railway tracks (ROADS) was obtained by differentiating the city area over the area of real
Fig. 1 Main habitat types and distribution of sample plots in Kraków, S Poland

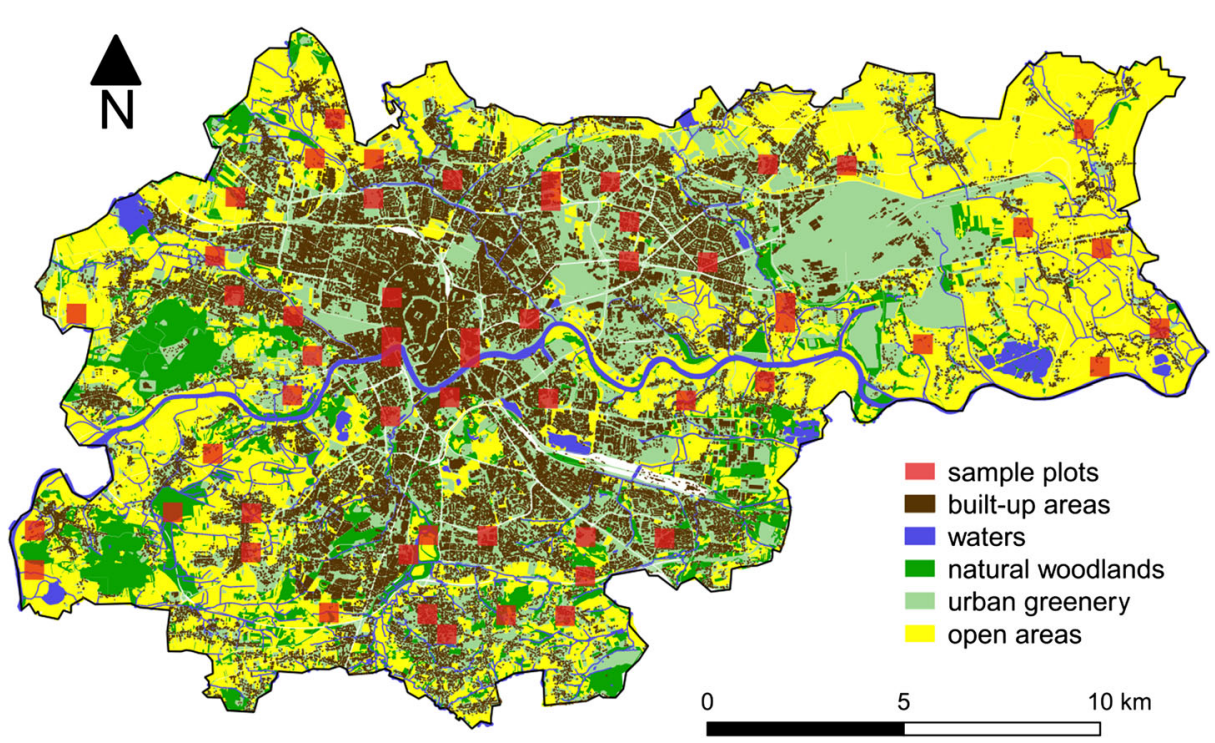


Table 1 List of environmental variables, their codes and descriptive statistics

\begin{tabular}{|c|c|c|c|c|c|}
\hline Variable & Code & Mean $\pm \mathrm{SD}$ & Range & Unit & Data source \\
\hline Area of buildings & BUILDINGS & $20094 \pm 20408$ & $0-93230$ & $\mathrm{~m}^{2}$ & (WODGiK 2009) \\
\hline Area of roads and railway tracks & ROADS & $13113 \pm 9708$ & $0-34164$ & $\mathrm{~m}^{2}$ & (UMK 2012) \\
\hline Distance to landfill sites & LANDFILLS & $8048 \pm 4035$ & $1426-16015$ & $\mathrm{~m}$ & (MIIP 2015) \\
\hline Distance to water & WATERS & $384 \pm 353$ & $21-1541$ & $\mathrm{~m}$ & (WODGiK 2009) \\
\hline Area of forest and natural woodlands & FORESTS & $18595 \pm 40090$ & $0-233443$ & $\mathrm{~m}^{2}$ & (UMK 2012) \\
\hline Area of urban greenery & GREENERY & $139164 \pm 82816$ & $0-234123$ & $\mathrm{~m}^{2}$ & (UMK 2012) \\
\hline Area of open spaces & OPENAREAS & $76371 \pm 83812$ & $0-240806$ & $\mathrm{~m}^{2}$ & (UMK 2012) \\
\hline Emission of pollutants & POLLUTION & $3.39 \pm 0.89$ & $2-5$ & class $\left(\mu \mathrm{g} / \mathrm{m}^{3}\right)$ & (MIIP 2015) \\
\hline Nocturnal noise emission & NOISE & $1.96 \pm 0.86$ & $1-4.03$ & class $(\mathrm{dB})$ & (MIIP 2015) \\
\hline Light pollution & LIGHT & $6.38 \pm 1.29$ & $3-8$ & class $\left(\mathrm{W} / \mathrm{cm}^{2} \times \mathrm{sr}\right)$ & (MBM 2015) \\
\hline Sources of food & FOODSOURCES & $13.4 \pm 14.1$ & $0-72$ & items & this study \\
\hline
\end{tabular}

vegetation habitats (UMK 2012) and surface waters (MIIP 2015). The layer obtained was validated with aerial photographs (GUGiK 2009). The area of buildings (BUILDINGS) was calculated based on the polygon vector layer of buildings (WODGiK 2009), summing the area of building outlines within a sample plot.

Distance to waters (WATERS) was calculated by measuring the distance from the centre of a sample plot to the nearest polygons of the layer of surface waters (WODGiK 2009). The distance to landfill sites (refuse tips) (LANDFILLS) was determined by calculating the distance from the centre of a sample plot to the nearest landfill site. The point layer with communal refuse tips contained two such sites that are accessible to birds, i.e. those at Barycz and Pleszów (MIIP 2015). The distance function matrix (QGIS 2013) was used for calculating the parameters based on distance (WATERS and LANDFILLS).

Emission of pollutants (POLLUTION) was determined on the basis of the pollution map of the city (MIIP 2015). From these the dominant class of the mean annual concentration of PM10 particulate matter in the air expressed in $\mu \mathrm{g} / \mathrm{m}^{3}$ (particle diameter $\leq 10 \mu \mathrm{m}$ ) was read off for each sample plot. The map shows the level of emissions in 5 contamination classes (1 $<20,2-20-30,3-30.1-40,4-40.1-60,5->60)$. The measurements were accurate to $10 \mu \mathrm{g} / \mathrm{m}^{3}$. The main sources of the high particulates concentration in Kraków are industrial facilities, motor vehicles and coal-fired stoves (WIOŚ 2014). Particulates concentrations were measured in 2013 by the Provincial Environmental Conservation Inspectorate (WIOŚ 2014). The resolution of the map (grid pixel size) was $500 \mathrm{~m}$.

The nocturnal noise emission parameter (NOISE) was determined from the map of road noise emission (MIIP 2015). The mean noise class weighted by its range area was calculated for every sample plot. Noise values during the hours of darkness (22:00-06:00 h) were used for these calculations. The map shows the noise level expressed in 9 classes of sound intensity $(\mathrm{dB})(1-<45,2-45-50,3-50.1-55,4-55.1-60,5-$
$60.1-65,6-65.1-70,7-70.1-75,8-75.1-80,9->80)$. The map was compiled jointly by the Provincial Environmental Conservation Inspectorate in Kraków and the Kraków City Council in 2008 (MIIP 2015). The map shows the data in the form of a vector layer.

Light pollution (LIGHT) was determined on the basis of the Light Pollution Map supplied by Microsoft Bing Maps (MBM 2015). The dominant class of light pollution was read off for each sample plot. The map shows the level of light pollution expressed in eight radiance classes $\left(\mathrm{W} / \mathrm{cm}^{2} \times \mathrm{SR}\right)$ (1-<0.25, 2-0.25-0.4, 3-0.41-1, 4-1.1-3, 5-3.1-6, 6-6.1-20, $7-20.1-40,8->40$; all values $\left.\times 10^{-9}\right)$ as measured in January 2015. The map's resolution (grid pixel size) was $463 \mathrm{~m}$.

Information on the magnitude of food sources (FOODSOURCES) was obtained during the transect counts. During each field survey the available food sources were counted: places where domestic animals were fed, active hen coops, active dovecotes, bird-feeders, rubbish bins and the enclosures where they are kept, organic refuse tips (compost heaps/bins), fruit trees still carrying fruit, manure heaps. The amount of food available in a given study plot was taken to be the mean from both seasons. In a given season the amount of food was the maximum recorded during two surveys.

\section{Data handling and analysis}

The numbers of species recorded (the sum of species from the two surveys per season) and the density of birds (the mean of two surveys per season) were determined in each of the two counting seasons (2014 and 2015). Concurrently, the total number of species recorded (the sum of species from two years) and density of birds (the mean from two years) were also calculated. The density was expressed as the number of individuals of all species per $1 \mathrm{~km}$ of transect, taking into account each time the real length of the surveyed transect.

For each study plot the interseasonal similarity in species composition and density was calculated using Sörensen's 
species similarity coefficient and Renkonen's density similarity coefficient. Species with a dominance of more than $10 \%$ were treated as dominants, those with $5-10 \%$ were regarded as subdominants, and those with $2-5 \%$ as accompanying species. Species making up less than $2 \%$ of an assemblage were regarded as accidental.

Wintering bird community traits (number of species, between-year species composition similarity, density and between-year density similarity) were used as response variables. In order to normalize the data distribution, square power transformation of the between-year species composition similarity variable and logarithmic transformation of the density variable were used. Environmental parameters (see Table 1) were used as explanatory variables. A generalized linear model with the normal logit function was used to predict the relationship between winter bird community traits and environmental variables (Bolker et al. 2009).

Akaike's information criterion (AIC) was used for model selection (Burnham and Anderson 2002). Because of the relatively small sample size $(\mathrm{n} / \mathrm{K}$ ratio $<40)$ a small-sample version of AIC with bias adjustment (AICc) was applied in the modelling. The resulting models were subsequently ranked in order of increasing AICc. The differences between the models with the lowest AICc were calculated ( $\triangle \mathrm{AICc}$ ) for each of the resulting models. Model likelihoods were normalized according to Akaike weights (w) to illustrate the weight of evidence of each model. The multimodel inference for all the candidate models was applied to evaluate the importance of each model predictor. AICc weights were summed for models containing a given variable. The predictor with the largest weight was considered the most important in model building (Burnham and Anderson 2002).

In order to illustrate directions and estimates of the most important environmental predictors we used generalized linear models. In this approach we used predictors with the highest $(p>0.8)$ probabilities of being in the best approximating models (based on AICc weights). All statistical procedures were performed using Statistica 10.0 software (StatSoft Inc. 2011).

\section{Results}

\section{Species composition and avifaunal structure}

A total of 64 species of birds was recorded. Those with the highest frequency (75\% and above) were Great Tit Parus major, Magpie Pica pica, Blackbird Turdus merula, Blue Tit Cyanistes caeruleus, Rook Corvus frugilegus, Fieldfare Turdus pilaris and House Sparrow Passer domesticus (Table 2). The dominant species in the assemblage were Feral Pigeon Columba livia f. urbana, Rook and Great Tit. The subdominants included House Sparrow, Magpie and
Fieldfare. Accompanying species were Black-headed Gull Chroicocephalus ridibundus, Jackdaw Corvus monedula, Blue Tit, Blackbird and Tree Sparrow Passer montanus. The other species were accidentals. The highest mean densities were achieved by Feral Pigeon, Rook, Great Tit, House Sparrow and Magpie (Table 2).

\section{Environmental parameters governing the number of species and its similarity}

The mean number of species found on the sample plots was 17.7 $\pm 4.9 \mathrm{SD}$ (median 18, quartile range 14-20). The model best explaining the number of wintering species contained the following parameters: sources of food, nocturnal noise emission, area of open spaces, area of buildings (or surface area of roads and railway tracks) and emission of pollutants (Table 3). The comparable model $(\triangle \mathrm{AICc} \leq 2)$ did not contain the pollutant emission parameter, or additionally did not contain the building area and road surface area parameters. Of all the variables analysed, nocturnal noise emission and area of open spaces (exerting a negative effect on the number of species) and sources of food (with a positive effect) exhibited the greatest likelihood of entering the model best explaining the number of wintering species (Tables 7 and 8 ).

The interseasonal coefficient of similarity of the number of species (Sörensen's index) on the sample plots had a mean value of $0.65 \pm 0.13 \mathrm{SD}$ (median 0.58 , quartile range 0.58 0.75 ). The models best explaining the interseasonal similarity of the species composition contained the following parameters: area of open spaces, area of buildings, surface area of roads and railway tracks, distance to landfill sites and emission of pollutants. The comparable model $(\Delta \mathrm{AICc}=0.7) \mathrm{did}$ not contain pollutant emission (Table 4). Of all the variables analysed, area of open spaces and area of buildings (having a negative effect on species composition similarity) and road surface area and distance to landfill sites (with a positive effect) exhibited the greatest likelihood of entering the model best explaining the similarity of the species composition (Tables 7 and 8).

\section{Environmental parameters governing density and its similarity}

The mean density of birds on the sample plots was 89.6 ind./km $\pm 63.3 \mathrm{SD}$ (median 76 , quartile range 53-117). The model best explaining the density of wintering species contained the following parameters: area of urban greenery, light pollution, nocturnal noise emission, sources of food and surface area of roads and railway tracks. The comparative model $(\triangle \mathrm{AICc}=2.1)$ did not contain road surface area (Table 5). Area of urban greenery, light pollution and sources of food (exerting a positive effect on the density of birds), and also nocturnal 
Table 2 Frequency, density (ind./km of transect) and dominance of the wintering bird assemblage in the urbanized habitats of Kraków, S Poland

\begin{tabular}{|c|c|c|c|c|c|c|}
\hline \multirow{2}{*}{$\begin{array}{l}\text { Species } \\
\text { Parus major }\end{array}$} & \multirow{2}{*}{$\begin{array}{l}\text { Frequency }(\%) \\
100\end{array}$} & \multicolumn{2}{|c|}{ Density $($ mean \pm SD) } & \multicolumn{2}{|c|}{ Density (median; quartiles range) } & \multirow{2}{*}{$\frac{\text { Dominance }(\%)}{12.3}$} \\
\hline & & 8.0 & 5.5 & 9.4 & $5.6-15.1$ & \\
\hline Pica pica & 95 & 5.2 & 2.6 & 4.5 & $1.4-7.5$ & 5.9 \\
\hline Turdus merula & 91 & 2.1 & 1.0 & 1.3 & $0.4-3$ & 2.2 \\
\hline Cyanistes caeruleus & 89 & 2.4 & 1.6 & 2.8 & $1.2-4.7$ & 3.7 \\
\hline Corvus frugilegus & 84 & 18.8 & 7.0 & 5.8 & $1.2-18.5$ & 15.6 \\
\hline Passer domesticus & 75 & 8.8 & 3.3 & 3.0 & $0.1-9.6$ & 7.3 \\
\hline Turdus pilaris & 75 & 11.5 & 2.4 & 0.6 & $0.2-5$ & 5.4 \\
\hline Corvus monedula & 71 & 5.1 & 2.0 & 2.1 & $0-6.3$ & 4.5 \\
\hline Streptopelia decaocto & 68 & 2.7 & 0.8 & 0.6 & $0-2.3$ & 1.9 \\
\hline Passer montanus & 64 & 3.0 & 0.9 & 0.7 & $0-2.4$ & 2.0 \\
\hline Carduelis carduelis & 61 & 3.2 & 0.7 & 0.4 & $0-1.2$ & 1.6 \\
\hline Garrulus glandarius & 61 & 0.9 & 0.4 & 0.2 & $0-1.1$ & 0.8 \\
\hline Spinus spinus & 55 & 1.9 & 0.5 & 0.2 & $0-1$ & 1.2 \\
\hline Columba livia f. urbana & 52 & 32.9 & 8.9 & 0.1 & $0-21.9$ & 19.8 \\
\hline Dendrocopos major & 50 & 0.7 & 0.2 & 0.0 & $0-0.4$ & 0.4 \\
\hline Pyrrhula pyrrhula & 50 & 0.8 & 0.2 & 0.0 & $0-0.8$ & 0.5 \\
\hline Fringilla coelebs & 46 & 0.9 & 0.2 & 0.0 & $0-0.4$ & 0.5 \\
\hline Coccothraustes coccothraustes & 43 & 0.9 & 0.3 & 0.0 & $0-0.9$ & 0.6 \\
\hline Sitta europaea & 39 & 1.1 & 0.3 & 0.0 & $0-0.3$ & 0.6 \\
\hline Aegithalos caudatus & 38 & 1.1 & 0.3 & 0.0 & $0-0.8$ & 0.7 \\
\hline Phasianus colchicus & 36 & 1.9 & 0.4 & 0.0 & $0-0.5$ & 0.8 \\
\hline Chloris chloris & 32 & 1.8 & 0.3 & 0.0 & $0-0.3$ & 0.7 \\
\hline Corvus cornix & 32 & 0.9 & 0.1 & 0.0 & $0-0.2$ & 0.3 \\
\hline Certhia brachydactyla & 29 & 0.1 & 0.0 & 0.0 & $0-0.2$ & 0.1 \\
\hline Emberiza citrinella & 27 & 1.4 & 0.3 & 0.0 & $0-0.2$ & 0.6 \\
\hline Sturnus vulgaris & 27 & 3.4 & 0.3 & 0.0 & $0-0.2$ & 0.6 \\
\hline Regulus regulus & 25 & 0.4 & 0.1 & 0.0 & $0-0$ & 0.2 \\
\hline Anas platyrhynchos & 20 & 6.5 & 0.8 & 0.0 & $0-0$ & 1.7 \\
\hline Troglodytes troglodytes & 20 & 0.2 & 0.0 & 0.0 & $0-0$ & 0.1 \\
\hline Buteo buteo & 18 & 0.2 & 0.0 & 0.0 & $0-0$ & 0.1 \\
\hline Chroicocephalus ridibundus & 18 & 17.5 & 2.0 & 0.0 & $0-0$ & 4.5 \\
\hline Picus viridis & 18 & 0.2 & 0.0 & 0.0 & $0-0$ & 0.1 \\
\hline Accipiter nisus & 16 & 0.1 & 0.0 & 0.0 & $0-0$ & + \\
\hline Certhia familiaris & 14 & 0.1 & 0.0 & 0.0 & $0-0$ & 0.1 \\
\hline Erithacus rubecula & 13 & 0.1 & 0.0 & 0.0 & $0-0$ & + \\
\hline Falco tinnunculus & 13 & 0.2 & 0.0 & 0.0 & $0-0$ & 0.1 \\
\hline Poecile palustris & 13 & 0.9 & 0.1 & 0.0 & $0-0$ & 0.2 \\
\hline Turdus philomelos & 9 & 0.2 & 0.0 & 0.0 & $0-0$ & + \\
\hline Dendrocopos minor & 7 & 0.1 & 0.0 & 0.0 & $0-0$ & + \\
\hline Dendrocopos syriacus & 7 & 0.1 & 0.0 & 0.0 & $0-0$ & + \\
\hline Fulica atra & 7 & 2.8 & 0.3 & 0.0 & $0-0$ & 0.6 \\
\hline Alauda arvensis & 5 & 0.1 & 0.0 & 0.0 & $0-0$ & + \\
\hline Corvus corax & 5 & 0.0 & 0.0 & 0.0 & $0-0$ & + \\
\hline Larus canus & 5 & 0.6 & 0.1 & 0.0 & $0-0$ & 0.1 \\
\hline Phalacrocorax carbo & 5 & 0.1 & 0.0 & 0.0 & $0-0$ & + \\
\hline Linaria cannabina & 4 & 0.6 & 0.1 & 0.0 & $0-0$ & 0.1 \\
\hline Cygnus olor & 4 & 5.5 & 0.5 & 0.0 & $0-0$ & 1.2 \\
\hline Dendrocopos medius & 4 & 0.0 & 0.0 & 0.0 & $0-0$ & + \\
\hline Larus cachinnans & 4 & 0.1 & 0.0 & 0.0 & $0-0$ & + \\
\hline
\end{tabular}


Table 2 (continued)

\begin{tabular}{|c|c|c|c|c|c|c|}
\hline \multirow{2}{*}{$\frac{\text { Species }}{\text { Picus canus }}$} & \multirow{2}{*}{$\begin{array}{l}\text { Frequency }(\%) \\
4\end{array}$} & \multicolumn{2}{|c|}{ Density (mean \pm SD) } & \multicolumn{2}{|c|}{ Density (median; quartiles range) } & \multirow{2}{*}{$\begin{array}{l}\text { Dominance }(\%) \\
+\end{array}$} \\
\hline & & 0.0 & 0.0 & 0.0 & $0-0$ & \\
\hline Poecile montanus & 4 & 0.1 & 0.0 & 0.0 & $0-0$ & + \\
\hline Accipiter gentilis & 2 & 0.0 & 0.0 & 0.0 & $0-0$ & + \\
\hline Alcedo atthis & 2 & 0.0 & 0.0 & 0.0 & $0-0$ & + \\
\hline Anser anser & 2 & 0.0 & 0.0 & 0.0 & $0-0$ & + \\
\hline Asio otus & 2 & 0.0 & 0.0 & 0.0 & $0-0$ & + \\
\hline Aythya ferina & 2 & 0.1 & 0.0 & 0.0 & $0-0$ & + \\
\hline Aythya fuligula & 2 & 0.4 & 0.0 & 0.0 & $0-0$ & 0.1 \\
\hline Bucephala clangula & 2 & 0.1 & 0.0 & 0.0 & $0-0$ & + \\
\hline Dryocopus martius & 2 & 0.1 & 0.0 & 0.0 & $0-0$ & + \\
\hline Emberiza schoeniclus & 2 & 0.0 & 0.0 & 0.0 & $0-0$ & + \\
\hline Fringilla montifringilla & 2 & 0.1 & 0.0 & 0.0 & $0-0$ & + \\
\hline Lophophanes cristatus & 2 & 0.0 & 0.0 & 0.0 & $0-0$ & + \\
\hline Perdix perdix & 2 & 0.1 & 0.0 & 0.0 & $0-0$ & + \\
\hline Turdus viscivorus & 2 & 0.0 & 0.0 & 0.0 & $0-0$ & + \\
\hline
\end{tabular}

noise emission (with a negative effect) were the variables with the greatest likelihood of entering the model best explaining the density of wintering birds (Tables 7 and 8 ).

Table 3 Sets of candidate models explaining the number of bird species wintering in an urbanized environment (Kraków, S Poland; for parameters, see Table 1). The number of variables (K), Akaike's
The interseasonal coefficient of similarity of bird density (Renkonen's index) on the sample plots had a mean value of $59.0 \pm 19.1 \mathrm{SD}$ (median 60.9, quartile range 43.9-74.6). The

information criterion for small samples (AICc), the difference between the given model and the most parsimonious model ( $\triangle \mathrm{AICc})$ and the Akaike weight (w) are reported for each model

\begin{tabular}{|c|c|c|c|c|}
\hline No & Model & $\mathrm{AICc}$ & $\Delta \mathrm{AICc}$ & $\mathrm{w}$ \\
\hline 1 & FOODSOURCES + NOISE + OPENAREAS + BUILDINGS + POLLUTION & 322.0 & 0.0 & 0.287 \\
\hline 2 & FOODSOURCES + NOISE + OPENAREAS + ROADS + POLLUTION & 322.9 & 0.9 & 0.182 \\
\hline 3 & FOODSOURCES + NOISE + OPENAREAS + BUILDINGS & 323.7 & 1.7 & 0.122 \\
\hline 4 & FOODSOURCES + NOISE + OPENAREAS + ROADS & 324.0 & 2.0 & 0.106 \\
\hline 5 & FOODSOURCES + NOISE + OPENAREAS & 324.0 & 2.0 & 0.104 \\
\hline 6 & FOODSOURCES + NOISE + POLLUTION & 324.8 & 2.8 & 0.071 \\
\hline 7 & FOODSOURCES + NOISE + LANDFILLS & 325.9 & 3.9 & 0.040 \\
\hline 8 & FOODSOURCES + NOISE & 326.2 & 4.2 & 0.035 \\
\hline 9 & NOISE + OPENAREAS & 327.0 & 5.0 & 0.023 \\
\hline 10 & NOISE + POLLUTION & 328.6 & 6.6 & 0.011 \\
\hline 11 & NOISE + GREENERY & 329.0 & 7.0 & 0.008 \\
\hline 12 & LANDFILLS + NOISE & 329.8 & 7.9 & 0.006 \\
\hline 13 & NOISE & 330.1 & 8.1 & 0.005 \\
\hline 14 & ROADS & 340.0 & 18.0 & 0.000 \\
\hline 15 & LANDFILLS & 341.8 & 19.8 & 0.000 \\
\hline 16 & BUILDINGS & 341.9 & 19.9 & 0.000 \\
\hline 17 & FOODSOURCES & 341.9 & 19.9 & 0.000 \\
\hline 18 & GREENERY & 342.9 & 20.9 & 0.000 \\
\hline 19 & WATERS & 342.9 & 21.0 & 0.000 \\
\hline 20 & OPENAREAS & 343.1 & 21.1 & 0.000 \\
\hline 21 & POLLUTION & 343.1 & 21.2 & 0.000 \\
\hline 22 & LIGHT & 343.3 & 21.3 & 0.000 \\
\hline 23 & FORESTS & 343.4 & 21.4 & 0.000 \\
\hline
\end{tabular}


Table 4 Sets of candidate models explaining between-year species composition similarity (Sörensen's index) of birds wintering in an urbanized environment (Kraków, S Poland; for parameters, see reported for each model
Table 1). The number of variables (K), Akaike's information criterion for small samples (AICc), the difference between the given model and the most parsimonious model ( $\triangle \mathrm{AICc})$ and the Akaike weight $(\mathrm{w})$ are

\begin{tabular}{|c|c|c|c|c|}
\hline No & Model & $\mathrm{AICc}$ & $\Delta \mathrm{AICc}$ & $\mathrm{w}$ \\
\hline 1 & OPENAREAS + BUILDINGS + ROADS + LANDFILLS + POLLUTION & -69.5 & 0.0 & 0.519 \\
\hline 2 & OPENAREAS + BUILDINGS + ROADS + LANDFILLS & -68.8 & 0.7 & 0.374 \\
\hline 3 & OPENAREAS + BUILDINGS + ROADS & -65.2 & 4.3 & 0.060 \\
\hline 4 & OPENAREAS + POLLUTION + LANDFILLS & -62.4 & 7.1 & 0.015 \\
\hline 5 & OPENAREAS + BUILDINGS + LANDFILLS & -62.3 & 7.2 & 0.014 \\
\hline 6 & OPENAREAS + POLLUTION & -59.9 & 9.6 & 0.004 \\
\hline 7 & OPENAREAS + BUILDINGS & -59.6 & 9.9 & 0.004 \\
\hline 8 & OPENAREAS + LANDFILLS & -59.5 & 10.0 & 0.004 \\
\hline 9 & OPENAREAS + FOODSOURCES & -59.2 & 10.3 & 0.003 \\
\hline 10 & OPENAREAS & -58.9 & 10.6 & 0.003 \\
\hline 11 & GREENERY & -57.0 & 12.5 & 0.001 \\
\hline 12 & ROADS & -54.0 & 15.5 & 0.000 \\
\hline 13 & LIGHT & -50.6 & 18.9 & 0.000 \\
\hline 14 & FOODSOURCES & -47.0 & 22.5 & 0.000 \\
\hline 15 & NOISE & -46.8 & 22.8 & 0.000 \\
\hline 16 & WATERS & -45.6 & 24.0 & 0.000 \\
\hline 17 & BUILDINGS & -45.1 & 24.4 & 0.000 \\
\hline 18 & LANDFILLS & -44.8 & 24.7 & 0.000 \\
\hline 19 & POLLUTION & -44.1 & 25.4 & 0.000 \\
\hline 20 & FORESTS & -43.9 & 25.6 & 0.000 \\
\hline
\end{tabular}

model best explaining the interseasonal similarity of the density of wintering birds contained only light pollution parameter. The comparative models $(\triangle \mathrm{AICc}<2)$ additionally contained the area of buildings or road surface area, sources

Table 5 Sets of candidate models explaining the total density of birds wintering in an urbanized environment (Kraków, S Poland; for parameters, see Table 1). The number of variables (K), Akaike's of food and distance to landfill sites (Table 6). Of all the variables analysed, light pollution (with a positive effect) was the one most likely to enter the model best explaining the similarity of bird densities (Tables 7 and 8).

information criterion for small samples (AICc), the difference between the given model and the most parsimonious model ( $\triangle \mathrm{AICc})$ and the Akaike weight (w) are reported for each model

\begin{tabular}{|c|c|c|c|c|}
\hline No & Parameters & $\mathrm{AICc}$ & $\Delta \mathrm{AICc}$ & $\mathrm{w}$ \\
\hline 1 & GREENERY + LIGHT + NOISE + FOODSOURCES + ROADS & 95.8 & 0.0 & 0.632 \\
\hline 2 & GREENERY + LIGHT + NOISE + FOODSOURCES & 97.9 & 2.1 & 0.220 \\
\hline 3 & GREENERY + LIGHT + NOISE & 100.0 & 4.3 & 0.075 \\
\hline 4 & GREENERY & 101.5 & 5.7 & 0.036 \\
\hline 5 & GREENERY + LIGHT & 101.5 & 5.8 & 0.035 \\
\hline 6 & LIGHT & 107.7 & 12.0 & 0.002 \\
\hline 7 & OPENAREAS & 109.4 & 13.7 & 0.001 \\
\hline 8 & ROADS & 110.8 & 15.1 & 0.000 \\
\hline 9 & BUILDINGS & 112.8 & 17.0 & 0.000 \\
\hline 10 & POLLUTION & 118.1 & 22.4 & 0.000 \\
\hline 11 & FORESTS & 119.3 & 23.6 & 0.000 \\
\hline 12 & WATERS & 120.7 & 25.0 & 0.000 \\
\hline 13 & FOODSOURCES & 122.9 & 27.1 & 0.000 \\
\hline 14 & NOISE & 126.4 & 30.6 & 0.000 \\
\hline 15 & LANDFILLS & 126.4 & 30.6 & 0.000 \\
\hline
\end{tabular}


Table 6 Sets of candidate models explaining between-year density similarity (Renkonen's index) of birds wintering in an urbanized environment (Kraków, S Poland; for parameters, see Table 1). The number of variables (K), Akaike's information criterion for small samples (AICc), the difference between the given model and the most parsimonious model $(\triangle \mathrm{AICc})$ and the Akaike weight $(\mathrm{w})$ are reported for each model

\begin{tabular}{lllll}
\hline No. & Model & AICc & $\Delta$ AICc & w \\
\hline 1 & LIGHT & 475.7 & 0.0 & 0.204 \\
2 & LIGHT + BUILDINGS & 476.0 & 0.3 & 0.173 \\
3 & LIGHT + ROADS & 476.4 & 0.7 & 0.145 \\
4 & LIGHT + FOODSOURCES & 476.9 & 1.2 & 0.111 \\
5 & LIGHT + LANDFILLS & 477.1 & 1.4 & 0.101 \\
6 & LIGHT + WATERS & 477.7 & 2.0 & 0.076 \\
7 & LIGHT + GREENERY & 477.7 & 2.0 & 0.076 \\
8 & ROADS & 477.9 & 2.2 & 0.069 \\
9 & BUILDINGS & 479.0 & 3.3 & 0.040 \\
10 & GREENERY & 485.1 & 9.4 & 0.002 \\
11 & OPENAREAS & 485.1 & 9.4 & 0.002 \\
12 & WATERS & 490.6 & 14.9 & 0.000 \\
13 & POLLUTION & 490.6 & 14.9 & 0.000 \\
14 & NOISE & 491.3 & 15.6 & 0.000 \\
15 & FOODSOURCES & 493.6 & 17.9 & 0.000 \\
16 & FORESTS & 493.7 & 18.0 & 0.000 \\
17 & LANDFILLS & 494.1 & 18.4 & 0.000 \\
\hline
\end{tabular}

\section{Discussion}

The results of this work indicate that the urban effect, i.e. noise and light pollution, apart from purely habitat factors, provide a good explanation for the species richness, density and stability of bird assemblage wintering in urban areas. To date, the habitat factors governing wintering bird assemblages have not been well researched, while the urban effect as having an influence on the overwintering of birds has been overlooked altogether. Of prime importance to the species composition of breeding birds are the maturity and type of greenery (White et al. 2005; Palomino and Carrascal 2006; Stagoll et al. 2012), the size and fragmentation of habitats, as well as the degree to which an area is built up (Fernández-Juricic and Jokimäki 2001; Crooks 2004; Palomino and Carrascal 2006). The few papers dealing with the wintering period state only the following variables as influencing the species composition: habitat composition and geographical location (Tryjanowski et al. 2015c), type of buildings (Jokimäki and KaisanlahtiJokimäki 2012), density of bird-feeders (Tryjanowski et al. 2015b), density of buildings, density and height of trees and shrubs, length of woodland margin and distance to water and railway lines (Tilghman 1987). The present paper is the first to demonstrate that the urban effect (light and noise pollution) may shape bird assemblages wintering in urban areas.

Our results point to the negative correlation between noise and the number of species and their density. The effect of noise has so far been studied only with respect to the breeding period (Nemeth et al. 2013; Proppe et al. 2013): excessive levels of noise have been shown to lead to the homogenization of bird communities. Species with low-frequency calls may be drowned out by the noise of passing motor vehicles, which forces them to call more often, and that, in turn, entails a greater expenditure of energy (Francis et al. 2009; Nemeth et al. 2013). The upshot is that the least flexible species withdraw from very noisy environments (Proppe et al. 2013). In our opinion vocal communication is as important in winter as during the breeding season: species with a similar diet congregate in flocks, searching together for sources of food, and while foraging avail themselves of the common calls warning against predators. In addition, the use of communal roosts during winter enables the exchange of information relating to such roosts and to movements between them and foraging

Table 7 The AICc weights for each variable used in the model selection procedure (see Tables 3-6). The values are the probabilities of a given environmental predictor being in the best approximating model (predictors with $p>0.8$ are shown in bold)

\begin{tabular}{lllll}
\hline Parameter & Number of species & $\begin{array}{l}\text { Between-year species } \\
\text { composition similarity }\end{array}$ & $\begin{array}{c}\text { Density } \\
\text { density similarity }\end{array}$ \\
\hline BUILDINGS & 0.4086 & $\mathbf{0 . 9 7 0 2}$ & 0.0001 & 0.2125 \\
ROADS & 0.2886 & $\mathbf{0 . 9 5 2 4}$ & 0.6321 & 0.2148 \\
OPENAREAS & $\mathbf{0 . 8 2 4 2}$ & $\mathbf{0 . 9 9 8 7}$ & 0.0007 & 0.0018 \\
GREENERY & 0.0085 & 0.0010 & $\mathbf{0 . 9 9 7 2}$ & 0.0776 \\
FORESTS & 0.0000 & 0.0000 & 0.0000 & 0.0000 \\
WATERS & 0.0000 & 0.0000 & 0.0000 & 0.0762 \\
LANDFILLS & 0.0454 & $\mathbf{0 . 9 2 5 3}$ & 0.0000 & 0.1010 \\
FOODSOURCES & $\mathbf{0 . 9 4 7 1}$ & 0.0030 & $\mathbf{0 . 8 5 1 2}$ & 0.1114 \\
LIGHT & 0.0000 & 0.0000 & $\mathbf{0 . 9 6 2 6}$ & $\mathbf{0 . 8 8 6 9}$ \\
NOISE & $\mathbf{0 . 9 9 9 9}$ & 0.0000 & $\mathbf{0 . 9 2 6 0}$ & 0.0000 \\
POLLUTION & 0.5506 & 0.5380 & 0001 & 0.0001 \\
\hline
\end{tabular}


Table 8 Estimates $( \pm \mathrm{SE})$ and $95 \%$ confidence intervals (CI) of environmental predictors with high $(p>0.8)$ probabilities of being in the best approximating models (based on AICc weights - see Table 7) of winter bird community traits (number of species, between-year species composition similarity index, density and between-year density similarity index)

\begin{tabular}{|c|c|c|c|c|c|}
\hline \multicolumn{6}{|l|}{ Number of species } \\
\hline Parameter & Estimate & SE & Wald's stat & $95 \% \mathrm{CI}$ & $\mathrm{p}$ \\
\hline Intercept & 24.60 & 1.64 & 224.17 & $21.38-27.82$ & 0.000 \\
\hline NOISE & -3.60 & 0.67 & 28.47 & $-4.92--2.27$ & 0.000 \\
\hline FOODSOURCES & 0.10 & 0.04 & 7.17 & $0.03-0.18$ & 0.007 \\
\hline OPENAREAS & $-1.62 \mathrm{e}^{-5}$ & $6.73 \mathrm{e}^{-6}$ & 5.78 & $-2.94 \mathrm{e}^{-5}--2.99 \mathrm{e}^{-6}$ & 0.016 \\
\hline \multicolumn{6}{|c|}{ Between-year species composition similarity } \\
\hline Parameter & Estimate & SE & Wald's stat & $95 \% \mathrm{CI}$ & $\mathrm{p}$ \\
\hline Intercept & 0.43 & 0.05 & 66.68 & $0.33-0.53$ & 0.000 \\
\hline OPENAREAS & $-1.07 \mathrm{e}^{-6}$ & $2.68 \mathrm{e}^{-7}$ & 15.89 & $-1.60 \mathrm{e}^{-6}--5.43 \mathrm{e}^{-7}$ & 0.000 \\
\hline BUILDINGS & $-5.04 \mathrm{e}^{-6}$ & $1.33 \mathrm{e}^{-6}$ & 14.46 & $-7.64 \mathrm{e}^{-6}--2.44 \mathrm{e}^{-6}$ & 0.000 \\
\hline ROADS & $8.93 \mathrm{e}^{-6}$ & $2.92 \mathrm{e}^{-6}$ & 9.37 & $3.21 \mathrm{e}^{-6}-1.47 \mathrm{e}^{-5}$ & 0.002 \\
\hline LANDFILLS & $9.98 \mathrm{e}^{-6}$ & $4.00 \mathrm{e}^{-6}$ & 6.23 & $2.14 \mathrm{e}^{-6}-1.78 \mathrm{e}^{-5}$ & 0.013 \\
\hline \multicolumn{6}{|l|}{ Density } \\
\hline Parameter & Estimate & SE & Wald's stat & $95 \% \mathrm{CI}$ & $\mathrm{p}$ \\
\hline Intercept & 2.80 & 0.40 & 49.29 & $2.02-3.58$ & 0.000 \\
\hline GREENERY & $3.03 \mathrm{e}^{-6}$ & $1.21 \mathrm{e}^{-6}$ & 6.28 & $6.62 \mathrm{e}^{-7}-5.41 \mathrm{e}^{-6}$ & 0.012 \\
\hline LIGHT & 0.22 & 0.08 & 6.76 & $0.05-0.38$ & 0.009 \\
\hline NOISE & -0.24 & 0.09 & 6.83 & $-0.42--0.06$ & 0.009 \\
\hline FOODSOURCES & 0.01 & 0.01 & 5.04 & $0.00-0.02$ & 0.025 \\
\hline \multicolumn{6}{|c|}{ Between-year density similarity } \\
\hline Parameter & Estimate & SE & Wald's stat & $95 \% \mathrm{CI}$ & $\mathrm{p}$ \\
\hline Intercept & 9.57 & 11.01 & 0.75 & $-12.02-31.15$ & 0.385 \\
\hline LIGHT & 7.75 & 1.69 & 20.94 & $4.43-11.07$ & 0.000 \\
\hline
\end{tabular}

grounds. Therefore areas with a high noise level are avoided by significant number of species potentially wintering in urbanized habitats.

The results of our work show that artificial light is a factor providing a good explanation for the density of birds and its interseasonal similarity. Artificial lighting transforms the nighttime environment in urbanized habitats and light pollution may have physiological, ecological and evolutionary implications for animal populations. Laboratory studies of the effect of artificial light on birds have shown that this alters their natural biological clocks (Aschoff 1966). Light sources act unconditionally on some organisms by disrupting their orientation (Verheijen 1960); this may partly explain why birds tend to congregate in brightly lit places. However, light at night is considered as a major driver of change in timing of daily activity. Light pollution effect has been studied mainly during the breeding period and in the context of extended vocal activity associated with displaying behaviour (Miller 2006; Da Silva et al. 2015) and earlier development of reproductive system (Kempenaers et al. 2010; Dominoni et al. 2013). In contrast, the effect of artificial lights on the timing of behaviours during winter has received relatively little attention. Although birds exposed to light in the night show earlier onset of activity in the morning (Dominoni et al. 2014; Da Silva et al. 2014), some studies suggest that artificial light at night is not an important driver of the timing of foraging behaviour in winter period (Clewley et al. 2015). However, other results indicate that species are able to extend their activity period by utilising artificial light during the winter (Byrkjedal et al. 2012) and typically diurnal birds are capable of foraging at night under artificial illumination (Lebbin et al. 2007). We believe that the wintering bird density may change as a result of the extended photoperiod - this is probably to the advantage of urban dwellers. In areas brightly lit up by street lamps birds are likely to be active longer than in unilluminated areas, which is of especial importance during the short days of winter. Although, light pollution may reshape entire ecosystems, the impact of light at population or community levels remain major research gaps. In our study we show for the very first time that wintering bird assemblage is under strong influence of light pollution.

Our results have confirmed that the availability of food is one of the main factors affecting the number of wintering species and their density (Jokimaki et al. 1996; Atchison and Rodewald 2006). Birds in urban areas are less afraid of humans and often consume food supplied by people 
(Pulliainen 1963; Luniak 2004; Meissner et al. 2012; Møller et al. 2014; Tryjanowski et al. 2015a). The consumption of anthropogenic food is particularly important in winter, when natural sources of food are unavailable, vegetation growth having ceased and there being no insects (Moorcroft et al. 2002). One of the basic sources of food in urban areas are bird-feeders, where a large number of species wintering in a town or city find their food (Siriwardena et al. 2007; Jokimäki and Kaisanlahti-Jokimäki 2012); a high density of birdfeeders increases the chances of a larger number of species in an assemblage (Tryjanowski et al. 2015b). However, apart from the deliberate feeding of birds at bird-feeders, the food parameter that we analysed included other sources of nourishment, such as fruit on garden trees, food laid out for domestic and other animals associated with humans and rubbish bins, all of which can provide significant sources of food during the winter (Kwit et al. 2004; Bellebaum 2005).

Farmland supports a large number of species (Pino et al. 2000) and increases biodiversity (Söderström and Pärt 2000). Within the Kraków city limits there is a relatively large proportion of fields and other open spaces, mostly on the outskirts (Dubiel and Szwagrzyk 2008). These parts of the city, with quite a rural character, may provide a habitat for species typical of an agricultural landscape. Our results have shown, however, that the proportion of open spaces, e.g. farmland, in an urban landscape had a negative effect on the number of species and the interseasonal species composition similarity. This is because farm production has ceased and much of such land has been given over to the prospective housing development (Ciach 2012). The lack of farm production means that agricultural land no longer provides the varied and constant sources of food that might otherwise attract specialized species (Wilson et al. 1996; Moorcroft et al. 2002).

We have found that the area of urban greenery plays a significant part in shaping bird densities. The presence of treecovered spaces in a city provides birds with shelter and foraging sites; consequently, they are an important place where urban bird populations congregate (Lancaster and Rees 1979; Stagoll et al. 2012). The density and heights of trees and shrubs are factors favouring high numbers of birds (Tilghman 1987). Moreover, the lack of a typical understory layer and the considerable area of mown grass in parks and gardens are propitious to ground-foraging species like corvids, which usually occur in large flocks (Lancaster and Rees 1979; Sandström et al. 2006; Jadczyk and Drzeniecka-Osiadacz 2013).

Species diversity is the highest in the suburbs, where the density of buildings is lower (Lancaster and Rees 1979; Palomino and Carrascal 2006; Sushinsky et al. 2013). The present study has shown that the area of buildings acts negatively on the number of species, though positively on the density and its interseasonal similarity. Urban infrastructure has an adverse effect on avian species richness in that it restricts the available area of suitable habitat (Lancaster and Rees 1979; Sandström et al. 2006). In addition, tall buildings and a dense network of streets heighten the risk of collisions; mortality is therefore higher, which may lead to a population decline (Longcore and Rich 2004; Bujoczek et al. 2011). On the other hand, these factors may exert a positive influence on bird density and its stabilization where synanthropic species are concerned, which achieve high numbers in cities. The present work has shown the dominants and subdominants to include Feral Pigeon, Rook, Great Tit, Magpie, Jackdaw, Blackbird and House Sparrow species for which urban areas are their principal habitat during the winter. Jokimäki and Kaisanlahti-Jokimäki (2012) demonstrated that interseasonal similarity was the greatest in suburban areas, where the density of buildings is not so high. But the density of synanthropic species increases with rising degree of urbanization (Sacchi et al. 2002; Jadczyk and DrzenieckaOsiadacz 2013; Ciach and Fröhlich 2013). We are of the opinion that increases in building density leads to the homogenization of a city's bird assemblage: where building densities are very high, a small group of so-called urban-winners attains large numbers and forms a relatively stable core assemblage, which is responsible for its interseasonal similarity. Moreover, highly urbanized areas create temporally rather constant overwintering conditions, with an abundant supply of anthropogenic food, which is less affected by changing weather conditions or by intermittent food sources (e.g. vegetation phenology or mast years). The presence of buildings and communication routes also make for a warmer microclimate, which again acts in favour of synanthropic species (Jadczyk and Drzeniecka-Osiadacz 2013).

One of the parameters with a positive effect on the interseasonal similarity of the species composition was the distance to a landfill site. Large refuse tips in winter are the main foraging grounds for a number of gull species and corvids (Betleja and Meissner 2005; Meissner and Betleja 2007). Since refuse tips are a permanent presence in the urban landscape, they are regularly visited by these birds. Gulls and corvids include long-lived species, so once they have discovered this source of food, they probably revisit it every year (winter), which is reflected in the interseasonal similarity of the species composition.

\section{Conclusions}

The results of our study show that the species composition, density and similarity of the bird assemblage wintering in urban areas beyond habitat factors are governed by the urban effect, i.e. artificial light and noise pollution. Noise adversely affects the number of species and density, whereas artificial light has a positive effect on density and the interseasonal similarity of the assemblage. Moreover, species diversity and bird density are determined by the number of food sources. Any increase in the proportion of open spaces reduces the 
number of species, but larger areas of urban greenery enhance bird density. Urban infrastructure (buildings, roads, refuse tips) had a positive effect on the interseasonal stabilization of the species composition of wintering birds.

Acknowledgments We wish to express our gratitude to members of the Ornithological Section of the Foresters' Scientific Club of the Faculty of Forestry in Kraków for their help with the fieldwork. Financial support for this study was provided by the Polish Ministry of Science and Higher Education by statutory grant (DS 3404).

Open Access This article is distributed under the terms of the Creative Commons Attribution 4.0 International License (http:// creativecommons.org/licenses/by/4.0/), which permits unrestricted use, distribution, and reproduction in any medium, provided you give appropriate credit to the original author(s) and the source, provide a link to the Creative Commons license, and indicate if changes were made.

\section{References}

AQIE (2015) Air quality now - comparing cities - current situation http://airqualitynow.eu/comparing home.php. Accessed 14 Mar 2015

Aschoff J (1966) Circadian activity pattern with two peaks. Ecol Soc Am 47:657-662. doi:10.2307/1933949

Atchison KA, Rodewald AD (2006) The value of urban forests to wintering birds. Nat Areas J 26:280-288. doi:10.3375/0885-8608(2006 26[280:TVOUFT]2.0.CO;2

Bellebaum J (2005) Between the herring Gull Larus argentatus and the bulldozer: black-headed Gull Larus ridibundus feeding sites on a refuse dump. Ornis Fenn 82:166-171

Betleja J, Meissner W (2005) Wystepowanie ptaków krukowatych Corvidae na składowiskach odpadów w Polsce latach 2002-2004. In: Jerzak L, Kavanagh BP, Tryjanowski P, Ptaki krukowate Polski. Poznań

Bibby CJ, Burgess ND, Hill DA, Mustoe SH (2000) Bird census techniques. Academic Press, London

Bolker BM, Brooks ME, Clark CJ et al (2009) Generalized linear mixed models: a practical guide for ecology and evolution. Trends Ecol Evol 24:127-135. doi:10.1016/j.tree.2008.10.008

Bujoczek M, Ciach M, Yosef R (2011) Road-kills affect avian population quality. Biol Conserv 144:1036-1039. doi:10.1016/j. biocon.2010.12.022

Burnham KP, Anderson DR (2002) Model selection and multi-model inference: a practical information-theoretic approach, New York

Byrkjedal I, Lislevand T, Vogler S (2012) Do passerine birds utilise artificial light to prolong their diurnal activity during winter at northern latitudes? Ornis Nor 35:37-42. doi:10.15845/on.v35i0.269

Ciach M (2012) The winter bird community of rural areas in the proximity of cities: low density and rapid decrease in diversity. Pol J Ecol 60:193-199

Ciach M, Fröhlich A (2013) Habitat preferences of the Syrian woodpecker Dendrocopos syriacus in urban environments: an ambiguous effect of pollution. Bird Study 60:491-499. doi:10.1080 /00063657.2013.847899

Clewley GD, Plummer KE, Robinson RA et al (2015) The effect of artificial lighting on the arrival time of birds using garden feeding stations in winter: a missed opportunity? Urban Ecosyst. doi:10.1007/s11252-015-0516-y

Crooks K (2004) Avian assemblages along a gradient of urbanization in a highly fragmented landscape. Biol Conserv 115:451-462

Czech B, Krausman PR, Devers PK (2000) Economic associations among causes of species endangerment in the United States. Bioscience 50:593-601
Da Silva A, Samplonius JM, Schlicht E et al (2014) Artificial night lighting rather than traffic noise affects the daily timing of dawn and dusk singing in common European songbirds. Behav Ecol 25: 1037-1047. doi:10.1093/beheco/aru103

Da Silva A, Valcu M, Kempenaers B (2015) Light pollution alters the phenology of dawn and dusk singing in common European songbirds. Philos Trans R Soc Lond Ser B Biol Sci 370. doi:10.1098/rstb.2014.0126

Dominoni D, Quetting M, Partecke J (2013) Artificial light at night advances avian reproductive physiology. Proc Biol Sci 280:20123017. doi:10.1098/rspb.2012.3017

Dominoni DM, Carmona-Wagner EO, Hofmann M et al (2014) Individual-based measurements of light intensity provide new insights into the effects of artificial light at night on daily rhythms of urban-dwelling songbirds. J Anim Ecol 83:681692. doi:10.1111/1365-2656.12150

Dubiel E, Szwagrzyk J (2008) Atlas Roślinności Rzeczywistej Krakowa. Urząd Miasta Krakowa, Wydział Kształtowania Środowiska

Fernández-Juricic E, Jokimäki J (2001) A habitat island approach to conserving birds in urban landscapes: case studies from southern and northern Europe. Biodivers Conserv 10:2023-2043. doi:10.1023/A:1013133308987

Forman RTT, Reineking B, Hersperger AM (2002) Road traffic and nearby grassland bird patterns in a suburbanizing landscape. Environ Manag 29:782-800. doi:10.1007/s00267-001-0065-4

Francis CD, Ortega CP, Cruz A (2009) Noise pollution changes avian communities and species interactions. Curr Biol 19:1415-1419. doi:10.1016/j.cub.2009.06.052

Gering JC, Blair RB (1999) Predation on artificial bird nests along an urban gradient: predatory risk or relaxation in urban environments? Ecography (Cop) 22:532-541

GUGiK (2009) Główny Urząd Geodezji i Kartografii - Orfotomapa http://www.geoportal.gov.pl/. Accessed 11 Oct 2014

GUS (2014) Główny Urząd Statystyczny - Powierzchnia i ludność w przekroju terytorialnym w 2013 r. Warszawa

Jadczyk P, Drzeniecka-Osiadacz A (2013) Feeding strategy of wintering rooks Corvus frugilegus L. In urban habitats. Pol J Ecol 61:587-596

Jokimäki J, Kaisanlahti-Jokimäki ML (2012) The role of residential habitat type on the temporal variation of wintering bird assemblages in northern Finland. Ornis Fenn 89:20-33

Jokimaki J, Suhonen J, Inki K, Simo J (1996) Biogeographical comparison of winter bird assemblages in urban environments in Finland. J Biogeogr 23:179-386

Kempenaers B, Borgström P, Loës P et al (2010) Artificial night lighting affects dawn song, extra-pair siring success, and lay date in songbirds. Curr Biol 20:1735-1739. doi:10.1016/j.cub.2010.08.028

Kwit C, Levey DJ, Greenberg CH et al (2004) Cold temperature increases winter fruit removal rate of a bird-dispersed shrub. Oecologia 139: 30-34. doi:10.1007/s00442-003-1470-6

Lancaster RK, Rees WE (1979) Bird communities and the structure of urban habitats. Can J Zool 57:2358-2368. doi:10.1139/z79-307

Lebbin DJ, Harvey MG, Lenz TC et al (2007) Nocturnal migrants foraging at night by artificial light. Wilson J Ornithol 119:506-508. doi:10.1676/06-139.1

Lepczyk CA, Mertig AG, Liu J (2004) Assessing landowner activities related to birds across rural-to-urban landscapes. Environ Manag 33: 110-125. doi:10.1007/s00267-003-0036-Z

Liu Z, He C, Zhou Y, Wu J (2014) How much of the world's land has been urbanized, really? A hierarchical framework for avoiding confusion. Landsc Ecol 29:763-771. doi:10.1007/s10980-014-0034-y

Longcore T, Rich C (2004) Ecological light pollution. Front Ecol Environ 2:191-198. doi:10.1890/1540-9295(2004)002[0191:ELP]2.0.CO;2

Luniak M (2004) Synurbization - adaptation of animal wildlife to urban development. In: 4th International Wildlife Symposium. Tuscon, pp 50-55 
Marzluff J (2001) Worldwide urbanization and its effects on birds. In: Marzluff J, Bowman R, Donnelly R (eds) Avian ecology and conservation in an urbanizing world pp 19-47. doi:10.1007/978-14615-1531-9

MBM (2015) Microsoft Bing Maps - Light Pollution map. http://www. lightpollutionmap.info/ Accessed 7 Jul 2015

Mcdonald RI, Kareiva P, Forman RTT (2008) The implications of current and future urbanization for global protected areas and biodiversity conservation. Biol Conserv 141:1695-1703. doi:10.1016/j. biocon.2008.04.025

McDonnell MJ (1997) A Paradigm Shift. Urban Ecosyst 1:85-86. doi:10.1023/A:1018598708346

Mcintyre NE, Knowles-Yánez K, Hope D (2000) Urban ecology as an interdisciplinary field: differences in the use of "urban" between the social and natural sciences. Urban Ecosyst 4:5-24. doi:10.1023/A:1009540018553

McKinney ML (2002) Urbanization, biodiversity, and conservation. Bioscience 52:883. doi:10.1641/0006-3568(2002)052[0883 :UBAC]2.0.CO;2

Meissner W, Betleja J (2007) Skład gatunkowy, liczebność i struktura wiekowa mew Laridae zimujących na składowiskach odpadów komunalnych w Polsce. Notatki Ornitol 48:11-27

Meissner W, Rowiński P, Kleinschmidt L et al (2012) Zimowanie ptaków wodnych na terenach zurbanizowanych w Polsce w latach 2007 2009. Ornis Pol 53:249-273

MIIP (2015) Małopolska Infrastruktura Informacji Przestrzennej Geoportal MIIP http://miip.geomalopolska.pl/imap/. Accessed 14 Mar 2015

Miller MW (2006) Apparent effects of light pollution on singing behavior of American robins. Condor 108:130-139. doi:10.1650 /0010-5422(2006)108[0130:AEOLPO]2.0.CO;2

Møller AP (2009) Successful city dwellers: a comparative study of the ecological characteristics of urban birds in the western Palearctic. Oecologia 159:849-858. doi:10.1007/s00442-008-1259-8

Møller AP, Jokimäki J, Skorka P, Tryjanowski P (2014) Loss of migration and urbanization in birds: a case study of the blackbird (Turdus merula). Oecologia 175:1019-1027. doi:10.1007/s00442-0142953-3

Moorcroft D, Whittingham MJ, Bradbury RB, Wilson JD (2002) The selection of stubble fields by wintering granivorous birds reflects vegetation cover and food abundance. J Appl Ecol 39:535-547. doi:10.1046/j.1365-2664.2002.00730.x

Nemeth E, Pieretti N, Zollinger SA et al (2013) Bird song and anthropogenic noise: vocal constraints may explain why birds sing higher-frequency songs in cities. Proc Biol Sci 280: 20122798. doi:10.1098/rspb.2012.2798

Palomino D, Carrascal LM (2006) Urban influence on birds at a regional scale: a case study with the avifauna of northern Madrid province. Landsc Urban Plan 77:276-290.doi:10.1016/j. landurbplan.2005.04.003

Pino J, Rodà F, Ribas J, Pons X (2000) Landscape structure and bird species richness: implications for conservation in rural areas between natural parks. Landsc Urban Plan 49:35-48. doi:10.1016/S0169-2046(00)00053-0

Proppe DS, Sturdy CB, St. Clair CC (2013) Anthropogenic noise decreases urban songbird diversity and may contribute to homogenization. Glob Chang Biol 19:1075-1084. doi:10.1111/gcb.12098

Pulliainen E (1963) On the history, ecology and ethology of the mallards (Anas platyrhynchos) overwintering in Finland. Ornis Fenn 40:45-66

QGIS (2013) Quantum GIS Development Team - Quantum GIS Geographic Information System. 1.7.4-Wroclaw. Open Source Geospatial Project (OSGeo)
Rodewald AD, Shustack DP (2008) Consumer resource matching in urbanizing landscapes: are synanthropic species over-matching. Ecology 89:515-521. doi:10.1890/07-0358.1

Sacchi R, Gentilli A, Razzetti E, Barbieri F (2002) Effects of building features on density and flock distribution of feral pigeons Columba livia Var. domestica in an urban environment. Can J Zool 80:48-54. doi:10.1139/z01-202

Sandström UG, Angelstam P, Mikusiński G (2006) Ecological diversity of birds in relation to the structure of urban green space. Landsc Urban Plan 77:39-53. doi:10.1016/j.landurbplan.2005.01.004

Siriwardena GM, Stevens DK, Anderson GQA et al (2007) The effect of supplementary winter seed food on breeding populations of farmland birds: evidence from two large-scale experiments. J Appl Ecol 44:920-932. doi:10.1111/j.1365-2664.2007.01339.x

Söderström B, Pärt T (2000) Influence of landscape scale on farmland birds breeding in semi-natural pastures. Conserv Biol 14:522-533. doi:10.1046/j.1523-1739.2000.98564.x

Stagoll K, Lindenmayer DB, Knight E et al (2012) Large trees are keystone structures in urban parks. Conserv Lett 5:115-122. doi:10.1111/j.1755-263X.2011.00216.X

StatSoft Inc (2011) Statistica (data analysis software system), version 10

Sushinsky JR, Rhodes JR, Possingham HP et al (2013) How should we grow cities to minimize their biodiversity impacts? Glob Chang Biol 19:401-410. doi: $10.1111 / \mathrm{gcb} .12055$

Tilghman NG (1987) Characteristics of urban woodlands affecting winter bird diversity and abundance. For Ecol Manag 21:163-175. doi:10.1016/0378-1127(87)90040-5

Tryjanowski P, Morelli F, Skórka P et al (2015a) Who started first? Bird species visiting novel bird feeders. Sci Rep 5:11858. doi:10.1038/srep11858

Tryjanowski P, Skórka P, Sparks TH et al (2015b) Urban and rural habitats differ in number and type of bird feeders and in bird species consuming supplementary food. Environ Sci Pollut Res Int 22: 15097-15103. doi:10.1007/s11356-015-4723-0

Tryjanowski P, Sparks TH, Biaduń W et al (2015c) Winter bird assemblages in rural and urban environments: a national survey. PLoS One 10(6):e0130299. doi:10.1371/journal.pone.0130299

UMK (2012) Urząd Miasta Krakowa - Mapa roślinności rzeczywistej Miasta Krakowa http://zielony-krakow.um.krakow.pl:280/rosl/pl/. Accessed 11 Feb 2014

UNFPA (2014) United Nations Population Fund - Urbanization http://www.unfpa.org/urbanization. Accessed 3 Feb 2014

van Kamp I, Leidelmeijer K, Marsman G, de Hollander A (2003) Urban environmental quality and human well-being. Landsc Urban Plan 65:5-18. doi:10.1016/S0169-2046(02)00232-3

Verheijen FJ (1960) The mechanisms of the trapping effect of artificial light sources upon animals. Arch Néerlandaises Zool 13:1-107. doi: $10.1163 / 036551660 \mathrm{X} 00017$

White JG, Antos MJ, Fitzsimons JA, Palmer GC (2005) Non-uniform bird assemblages in urban environments: the influence of streetscape vegetation. Landsc Urban Plan 71:123-135. doi:10.1016/j. landurbplan.2004.02.006

Wilson JD, Taylor R, Muirhead LB (1996) Field use by farmland birds in winter: an analysis of field type preferences using resampling methods. Bird Study 43:320-332. doi:10.1080/00063659609461025

WIOŚ (2014) Wojewódzki Inspektorat Ochrony Środowiska - Raport o stanie środowiska w Województwie Małopolskim w 2013 roku. Kraków

WODGiK (2009) Wojewódzki Ośrodek Dokumentacji Geodezyjnej i Kartograficznej - Baza Danych Obiektów Topograficznych http://www.geomalopolska.pl/. Accessed 5 Oct 2014 